\title{
Optimization of coconut osmotic drying preceded by microwave treatment by Response Surface Methodology
}

\section{Otimização da desidratação osmótica de coco precedida de tratamento com microondas empregando Metodologia de} Superfície de Resposta

\author{
Azadeh Salimi $^{1 *}$ (1), Fatemeh Hoseinnia ${ }^{2}$ \\ ${ }^{1}$ Semnan University, Faculty of Veterinary, Semnan Province - Iran \\ ${ }^{2}$ Islamic Azad University, Tehran - Iran
}

*Corresponding Author: Azadeh Salimi, Veterinary Department, Semnan University, Semnan-Damghan Road, Semnan City, Semnan Provinve - Iran, e-mail: a.salimi@semnan.ac.ir

Cite as: Salimi, A., \& Hoseinnia, F. (2020). Optimization of coconut osmotic drying preceded by microwave treatment by Response Surface Methodology. Brazilian Journal of Food Technology, 23, e2018249. https://doi.org/10.1590/1981-6723.24918

\begin{abstract}
Osmotic dehydration is an intermediate stage in drying processes in which water is extracted using a hypertonic solution, but it is a slow process, especially in hard foods such as coconut. Microwaves use an electromagnetic field which can raise the temperature in the depth of samples as a result of friction, which facilitates mass transfer due to molecular expansion and increased porosity. The aim of this study was to investigate the effect of a microwave pre-treatment on the quality of the osmotic drying of coconut and optimize the whole process by response surface methodology (RSM). The independent variables were the microwave power $\left(X_{1}\right)$, the sugar solution concentration $\left(X_{2}\right)$ and the duration of the process $\left(X_{3}.\right)$. The responses (dependent variables) were the moisture content difference (MD), weight reduction (WR), water loss (WL) and solids gain (SG). The results showed that the linear terms of $X_{2}$ and $X_{3}$ had significant effects on all the dependent variables but the linear term of $X_{1}$ only significantly affected $W L, S G$ and $W R$ $(p<0.05)$. The interaction of $X_{1} X_{2}$ significantly affected $W L$ and $W R$ and the interaction of $X_{2} X_{3}$ significantly affected all the dependent variables, but the interaction of $X_{1} X_{3}$ only significantly affected $M D(p<0.05)$. On the other hand, $\mathrm{X}_{2}{ }^{2}$ significantly affected SG and WR $(p<0.05)$. The two-factor model (2FI) was able to express the changes in $M D$ and $W L$, but only the quadratic model adequately fitted $S G$ and $W R$, the determination coefficients being $0.98,0.99,0.99$ and 0.99 respectively. Finally, the optimized condition was obtained with a power of 900 watts, concentration of $47.80 \%$ and duration of 5 hours.
\end{abstract}

Keywords: RSM; Weight reduction; Water loss; Solids gain; Moisture content difference. 


\section{Resumo}

A desidratação osmótica é uma etapa intermediária em processos de secagem, em que a água é extraída usando uma solução hipertônica, mas é um processo lento, especialmente em alimentos duros como coco. As micro-ondas usam um campo eletromagnético que consegue aumentar a temperatura na profundidade de amostras como resultado de fricção, que facilita a transferência de massa em razão de expansão molecular e aumento da porosidade. O objetivo deste estudo for investigar o efeito de um pré-tratamento com micro-ondas na qualidade da secagem osmótica de coco e otimizar todo o processo pela metodologia de superfície de resposta (MSR). As variáveis independentes foram a potência das micro-ondas $\left(\mathrm{X}_{1}\right)$, a concentração da solução de açúcar $\left(\mathrm{X}_{2}\right)$ e o tempo de processo $\left(\mathrm{X}_{3}\right)$. As respostas (variáveis dependentes) foram a diferença em conteúdo de umidade (MD), a diminuição de peso (WR), a perda de água (WL) e o ganho em sólidos (SG). Os resultados mostraram que os termos lineares de $\mathrm{X}_{2}$ e $\mathrm{X}_{3}$ tiveram efeitos significativos em todas as variáveis dependentes, mas o termo linear de $X_{1}$ somente teve efeitos significativos em $W L$, SG e WWR $(p<0,05)$. $A$ interação $X_{1} X_{2}$ afetou WL e WR significativamente e a interação $X_{2} X_{3}$ afetou todas as variáveis dependentes significativamente, mas a interação $\mathrm{X}_{1} \mathrm{X}_{3}$ apenas afetou MD significativamente $(p<0,05)$. $\mathrm{O}$ termo $\mathrm{X}_{2}^{2}$ afetou SG e WR significativamente $(p<0,05)$. O modelo de dois fatores $(2 \mathrm{FI})$ expressou as mudanças em $M D$ e $W L$, mas apenas o modelo quadrático se ajustou a SG e WR, com os seguintes coeficientes de determinação: 0,98, 0,99, 0,99 e 0,99, respectivamente. Finalmente, a condição otimizada foi obtida com uma potência de 900 watts, concentração de $47,80 \%$ e duração de cinco horas.

Palavras-chave: Metodologia de superfície de resposta; Redução de peso; Perda de água; Ganho de sólidos; Diferença de umidade.

\section{Introduction}

Coconut (scientific name of Coco nucifera L.) is one of the most important crops in tropical and subtropical regions (Kamalanathan \& Meyyappan, 2014). It has some medicinal properties such as anti-inflammatory, pain relief, moisturizing and antioxidant properties. The coconut palm is grown to produce various products, including oil and milk from the mature coconut. The mature coconut shell is used to produce active carbon and the green coconut shell is used as a natural absorbent in the removal of toxic metals (Sousa et al., 2007). In recent years, delicious coconut snacks have been produced, such as small dehydrated cut pieces (Silva et al., 2014).

Drying was one of the earliest methods of food processing and storage, involving the use of heat under controlled conditions to remove most of the water from a food. Of the various drying methods, hot air oven drying is the most common one used to preserve fruits and vegetables etc., but it has certain disadvantages such as shrinkage, reduction in the rehydration ratio and undesirable changes in colour, texture, taste and nutritional value, so food technologists are innovating new technologies to improve the quality of dried products (Sivasakthi \& Sangeetha, 2012).

Osmotic dehydration is a substitute for the intermediate stage or as a pre-treatment technology in the food industry (Eroglu \& Yildiz, 2010). This process consists of the immersion of a food sample in a hypertonic solution, allowing for the partial removal of water, solute uptake and finally a decrease in the water activity $\left(a_{w}\right)$. It has some benefits such as reducing the heat damage, leading to preservation of the flavour, colour, nutritional value and structural quality (Herman-Lara et al., 2013; Ramya \& Jain, 2017).

Investigations have shown that increasing the temperature and concentration of the osmotic solution result in increases in the water loss and solids gain and can reduce the total duration of the process, but it is still a lengthy process (Behnam et al., 2013; Kamalanathan \& Meyyappan, 2014; Corrêa et al., 2016). Due to this 
problem, research is being carried out aimed at reducing the duration and increasing the final quality of osmo-dried products. It has been reported that a combination of osmotic drying with other technologies such as pulsed vacuum, ultrasonic and microwave pre-treatments, can lead to a quicker lowering of the moisture content leading to an improvement in the final product quality (Sabahi et al., 2013; Corrêa et al., 2016; Junqueira et al., 2018).

One of these innovative methods is the use of microwaves. Incorporating the use of microwaves in different processes is becoming more and more popular, because it is a fast, economic and energy saving process which can improve the quality of the final products. Inside the microwave oven, the inside of the material becomes very hot due to extreme fluctuations of the polar molecules, especially water, and thus the resulting product is more expanded and porous due to the movement of steam from the inside to the outside (Durance \& Wang, 2002; Zhang et al., 2006; Valadez-Carmona et al., 2016). It has been reported that a microwave pre-treatment can improve osmotic dehydration (Sabahi et al., 2013).

Thus the aim of this study was to determine the optimum conditions for the microwave -osmosis of the coconut drying process by using response surface methodology to maximize the percentage water loss and weight loss and minimize the adsorption of solids and the final moisture content.

\section{Material and methods}

Mature coconuts (10 months old) were purchased from the local market. Sucrose and distilled water were purchased from the Qatran Shimi Company (Iran) and Noor and Niroo Company (Iran), respectively. The equipment used included a 900 watt microwave oven (Samsung, CE3110N manufactured in Malaysia), a hot air oven (Memmert, 400 ULM, manufactured in Germany), a water bath (Memmert, WNB7, manufactured in Germany), a 0.001 digital balance (Sartorius, TE313S, manufactured in Germany), desiccator, cutting knives and drying paper.

To prepare the samples, the coconut meat was separated from its crust, and then cut into $0.5 \times 1 \times 1 \mathrm{~cm}$ cubes using a sharp knife. The initial moisture content of the coconuts was determined and $50 \mathrm{~g}$ of coconut cubes placed first in the microwave oven for 20 seconds and then in sugar solutions at $40{ }^{\circ} \mathrm{C}$. The proportion of fruit to solution was $1: 5 \mathrm{w} / \mathrm{w}$.

After removing the surface moisture using drying paper, the samples were weighed to determine the WL and SG and finally placed in the hot air oven at $65^{\circ} \mathrm{C}$ to reach a $7 \%$ moisture content on a wet weight basis (Askari et al., 2004; Quanhong \& Caili, 2005; Chenlo et al., 2006; Misljenovic et al., 2012; Sabahi et al., 2013; Kamalanathan \& Meyyappan, 2014).

\subsection{Moisture Content Difference (MD)}

The moisture content of the samples was determined according to the Association of Official Analytical Chemists (2005) procedure and calculated using Equation 1.

$M C=M i-M d / M d \times 100$

$\mathrm{MC}$ is the moisture content of the coconut samples on a dry weight basis, $\mathrm{M}_{\mathrm{i}}$ is the weight of the samples at time $i$ and $M_{d}$ is the weight of the dried samples (Equation 2).

$M D=M C_{i}-M C_{f}$

$\mathrm{MC}_{\mathrm{i}}$ is the initial moisture content of the coconut samples; and $\mathrm{MC}_{\mathrm{f}}$ is the final moisture content after osmotic drying. 


\subsection{Water Loss (WL)}

To measure the water loss, a determined weight of the samples was removed from the osmotic solution, placed in a petri dish and transferred to an oven at $105^{\circ} \mathrm{C}$. After reaching constant weight, the final weight was recorded and the rate of water loss calculated according to Equation 3 (Islam \& Flink, 1982).

$$
W L=[(W i \times X i)-(W r \times X r)] / W i \times 100
$$

$X_{i}$ and $X_{r}$ are the moisture contents of the fresh and dried samples, respectively; $W_{i}$ and $W_{r}$ are the initial weight of the samples and the weight of the dried samples (g), respectively; and $\mathrm{W}_{\mathrm{L}}$ is the decrease in moisture content (\%).

\subsection{Solids Gain (SG)}

The rate of solids gain was calculated according to Equation 4 using the parameters introduced previously (Islam \& Flink, 1982; Kamalanathan \& Meyyappan, 2014):

$$
S G=[W r \times(1-X r)-W i \times(1-X i)] / W i \times 100
$$

\subsection{Weight Reduction (WR)}

Weight loss was calculated according to Equation 5 (Kamalanathan \& Meyyappan, 2014).

$W R=W L-S G$

\subsection{Statistical analysis}

Response surface methodology was used to optimize the process. Design expert software, version 6.0.2, the composite center design, face center, alpha 1 and four central points in two replications were used to examine the effects of three independent variables including the microwave power $(0,450$ and 900 watts $)$, osmotic concentration $(20 \%, 45 \%$ and $70 \% \mathrm{w} / \mathrm{w})$ and the duration of the osmotic process (1, 3 and 5 hours) on the four dependent variables (responses) of WL, SG, MD and WR.

The significance or non- significance of the model coefficients were determined according to the P-value $(p<0.05)$. The quality of the appropriate models was investigated from the $\left(\mathrm{R}^{2}\right)$ and (fitted $\left.\mathrm{R}^{2}\right)$ and the lack of fit. Also, three-dimensional graphs and regression models were produced for a visual and graphical evaluation.

\section{Results and discussions}

Table 1 shows the data obtained from the 32 tests and the analyses of variance are shown in Tables 2 and 3. 
Optimization of coconut osmotic drying preceded by microwave treatment by Response Surface Methodology

Salimi, A., \& Hoseinnia, F.

Table 1. Experimental values of the dependent variables.

\begin{tabular}{|c|c|c|c|c|c|c|c|}
\hline Run & $\begin{array}{c}\text { Microwave } \\
\text { power } \\
\text { (watt) }\end{array}$ & $\begin{array}{c}\text { Osmotic } \\
\text { solution } \\
\text { concentration } \\
(\%)\end{array}$ & $\begin{array}{l}\text { Duration of } \\
\text { osmosis } \\
\text { (hour) }\end{array}$ & $\begin{array}{c}\text { Moisture } \\
\text { difference } \\
\text { MD (\%) }\end{array}$ & $\begin{array}{l}\text { Water loss } \\
\text { WL (\%) }\end{array}$ & $\begin{array}{c}\text { Solids gain } \\
\text { SG (\%) }\end{array}$ & $\begin{array}{c}\text { Weight } \\
\text { reduction } \\
\text { WR (\%) }\end{array}$ \\
\hline 1 & 450 & 45 & 1 & 6.05 & 8.545 & 2.895 & 5.65 \\
\hline 2 & 450 & 45 & 3 & 7.42 & 9.7998 & 3.0998 & 6.7 \\
\hline 3 & 900 & 20 & 5 & 1.08 & 2.3616 & 0.0188 & 2.55 \\
\hline 4 & 900 & 20 & 1 & 0.37 & 0.9149 & 0.0235 & 1.05 \\
\hline 5 & 0 & 20 & 1 & 0.36 & 0.5753 & 0.1253 & 0.45 \\
\hline 6 & 0 & 70 & 5 & 16.38 & 22.7786 & 6.9286 & 15.85 \\
\hline 7 & 0 & 20 & 1 & 0.35 & 0.5712 & 0.1212 & 0.45 \\
\hline 8 & 450 & 45 & 5 & 9.14 & 11.78 & 4.13 & 7.65 \\
\hline 9 & 0 & 70 & 1 & 9.44 & 12.5773 & 3.7817 & 8.7956 \\
\hline 10 & 450 & 20 & 3 & 0.7 & 1.3051 & 0.1051 & 1.2 \\
\hline 11 & 450 & 70 & 3 & 15.46 & 20.8882 & 5.7382 & 15.15 \\
\hline 12 & 0 & 45 & 3 & 7.29 & 9.2694 & 4.6217 & 4.6476 \\
\hline 13 & 450 & 70 & 3 & 15.56 & 20.8503 & 5.7003 & 15.15 \\
\hline 14 & 900 & 70 & 1 & 8.95 & 14.2358 & 1.9858 & 12.25 \\
\hline 15 & 450 & 45 & 3 & 7.33 & 9.7033 & 3.1033 & 6.6 \\
\hline 16 & 450 & 20 & 3 & 0.72 & 1.3069 & 0.1069 & 1.2 \\
\hline 17 & 0 & 20 & 5 & 1.08 & 1.8287 & 0.4787 & 1.35 \\
\hline 18 & 0 & 45 & 3 & 7.23 & 9.2249 & 4.6272 & 4.5977 \\
\hline 19 & 0 & 70 & 1 & 9.16 & 12.4133 & 3.6677 & 8.7456 \\
\hline 20 & 900 & 45 & 3 & 7.31 & 11.0831 & 2.3831 & 8.7 \\
\hline 21 & 900 & 70 & 5 & 19.25 & 25.7793 & 6.3293 & 19.45 \\
\hline 22 & 450 & 45 & 3 & 7.06 & 9.7554 & 3.1054 & 6.65 \\
\hline 23 & 0 & 20 & 5 & 1.07 & 1.8208 & 0.4708 & 1.35 \\
\hline 24 & 900 & 70 & 5 & 19.28 & 25.7293 & 6.3793 & 19.35 \\
\hline 25 & 900 & 20 & 5 & 1.08 & 2.3616 & 0.0183 & 2.55 \\
\hline 26 & 450 & 45 & 5 & 9.06 & 11.8373 & 4.1373 & 7.7 \\
\hline 27 & 0 & 70 & 5 & 15.82 & 22.6798 & 6.8298 & 15.85 \\
\hline 28 & 450 & 45 & 3 & 7.29 & 9.7971 & 3.0917 & 6.7 \\
\hline 29 & 450 & 45 & 1 & 6.02 & 8.4929 & 2.8929 & 5.6 \\
\hline 30 & 900 & 20 & 1 & 0.36 & 0.9657 & 0.0234 & 1.1 \\
\hline 31 & 900 & 45 & 3 & 7.34 & 11.0439 & 2.3939 & 8.65 \\
\hline 32 & 900 & 70 & 1 & 8.73 & 14.1821 & 1.9821 & 12.2 \\
\hline
\end{tabular}

Table 2. Analysis of variance for the determination coefficients of the fitted models for MD and WL.

\begin{tabular}{|c|c|c|c|c|c|c|}
\hline \multicolumn{4}{|c|}{ Moisture difference MD (\%) } & \multicolumn{3}{|c|}{ Water loss WL (\%) } \\
\hline Variables & $\begin{array}{l}\text { Regression } \\
\text { coefficients }\end{array}$ & F-value & P-value & $\begin{array}{l}\text { Regression } \\
\text { coefficients }\end{array}$ & F-value & P-value \\
\hline $\mathrm{X}_{0}($ Intercept $)$ & 7.30 & & & 10.20 & & \\
\hline \multicolumn{7}{|l|}{ Linear } \\
\hline $\mathrm{X}_{1}$ (Microwave power) & 0.28 & 2.63 & 0.1172 & 0.75 & 18.90 & 0.0002 \\
\hline $\mathrm{X}_{2}$ (Sugar concentration) & 6.54 & 1449.20 & $<0.0001$ & 8.91 & 2693.35 & $<0.0001$ \\
\hline $\mathrm{X}_{3}$ (Time of osmosis) & 2.17 & 159.77 & $<0.0001$ & 2.77 & 261.39 & $<0.0001$ \\
\hline \multicolumn{7}{|l|}{ 2FI } \\
\hline $\mathrm{X}_{1} \mathrm{X}_{2}$ & - & - & - & 0.48 & 6.24 & 0.0191 \\
\hline $\mathrm{X}_{1} \mathrm{X}_{3}$ & 0.45 & 5.55 & 0.0264 & - & - & - \\
\hline $\mathrm{X}_{2} \mathrm{X}_{3}$ & 1.97 & 105.50 & $<0.0001$ & 2.39 & $154 / 98$ & $<0.0001$ \\
\hline \multicolumn{7}{|l|}{ Quadratic } \\
\hline $\mathrm{X}^{2}{ }_{1}$ & - & - & - & - & - & - \\
\hline $\mathrm{X}^{2}{ }_{2}$ & - & - & - & - & - & - \\
\hline $\mathrm{X}^{2}{ }_{3}$ & - & - & - & - & - & - \\
\hline $\mathrm{R}^{2}$ & 0.9851 & & & 0.9918 & & \\
\hline Adj-R ${ }^{2}$ & 0.9823 & & & 0.9902 & & \\
\hline Lack of fit & 16.61 (Non-significant) & & & 15.28 (Non-significant) & & \\
\hline
\end{tabular}


Table 3. Analysis of variance for the determination coefficients of the fitted models for SG and WR.

\begin{tabular}{|c|c|c|c|c|c|c|}
\hline \multicolumn{4}{|c|}{ Solids gain SG (\%) } & \multicolumn{3}{|c|}{ Weight reduction WR (\%) } \\
\hline Variables & $\begin{array}{l}\text { Regression } \\
\text { coefficients }\end{array}$ & $\begin{array}{c}\text { F- } \\
\text { value }\end{array}$ & P-value & $\begin{array}{l}\text { Regression } \\
\text { coefficients }\end{array}$ & F-value & P-value \\
\hline $\mathrm{X}_{0}$ (Intercept) & 3.37 & & & 6.65 & & \\
\hline \multicolumn{7}{|l|}{ Linear } \\
\hline $\mathrm{X}_{1}($ Microwave power $)$ & -0.54 & 1.26 & 0.0005 & 1.29 & 98.75 & $<0.0001$ \\
\hline $\begin{array}{c}\mathrm{X}_{2} \text { (Sugar } \\
\text { concentration) }\end{array}$ & 2.43 & 178.29 & $<0.0001$ & 6.48 & 2496.55 & $<0.0001$ \\
\hline $\mathrm{X}_{3}$ (Time of osmosis) & 0.91 & 38.39 & $<0.0001$ & 1.87 & 207.64 & $<0.0001$ \\
\hline \multicolumn{7}{|l|}{2 2FI } \\
\hline $\mathrm{X}_{1} \mathrm{X}_{2}$ & - & - & - & 0.65 & 19.96 & 0.0001 \\
\hline $\mathrm{X}_{1} \mathrm{X}_{3}$ & - & - & - & - & - & - \\
\hline $\mathrm{X}_{2} \mathrm{X}_{3}$ & 0.9 & 37.98 & $<0.0001$ & 1.48 & 104.97 & $<0.0001$ \\
\hline \multicolumn{7}{|l|}{ Quadratic } \\
\hline $\mathrm{X}^{2}{ }_{1}$ & - & - & - & - & - & - \\
\hline $\mathrm{X}_{2}^{2}$ & -0.87 & 0.54 & 0.0008 & 1.15 & 29.42 & $<0.0001$ \\
\hline $\mathrm{X}_{3}^{2}$ & - & - & - & - & - & - \\
\hline $\mathrm{R}^{2}$ & 0.9918 & & & 0.9916 & & \\
\hline Adj-R ${ }^{2}$ & 0.9902 & & & 0.9896 & & \\
\hline Lack of fit & $5.83^{\text {(Non-significant) }}$ & & & $8.38^{\text {(Non-significant) }}$ & & \\
\hline
\end{tabular}

These results showed that, whereas in the case of MD and WL the quadratic models were not significant, for WR and SG they were selected as the best fitted models. The determination coefficients for MD, WL (2FI models), SG and WR (quadratic models) were 0.98, 0.99, 0.99 and 0.99 respectively. These determination coefficients showed that the selected models could adequately estimate the drying conditions.

The analysis of variance tables (Tables 2 and 3) showed that the variable with the most significant effect on MD was the sugar concentration, followed by the duration of the osmotic process, the interaction between the concentration and duration, and the interaction between the microwave power and duration, respectively $(p<0.05)$. Other parameters that had no significant effect were omitted from the model.

In the case of WL, the variable with the greatest influence was the sugar concentration. Followed by the duration of the osmotic process, the interaction between the concentration and duration, the microwave power and the interaction between the microwave power and concentration, respectively $(p<0.05)$. None of the second-order parameters had a significant effect on WL.

For SG, the concentration of the sugar solution had the most significant effect followed by the duration of osmosis, the interaction between the sugar concentration and duration, the microwave power and the second order parameter of sugar concentration, respectively $(p<0.05)$.

In the case of WR, as with the other dependent parameters, the sugar concentration was the most significant parameter followed by the duration, interaction between the sugar concentration and duration, the microwave power, the second order parameter of sugar concentration and the interaction between the microwave power and sugar concentration, respectively $(p<0.05)$.

A 3D plot of the combined effects of the independent variables on the dependent variables was produced and the combined and interaction effects of the independent variables are represented in Figures 1-7. 

Moisture content differences (\%)
Design points above predicted value
Design points below predicted value
0.35

19.28

$\mathrm{X} 1$ = A: Microwave

$\mathrm{X} 2$ = C: Time of osmosis

\section{Actual Factor}

B: Sugar concenteration $=45$

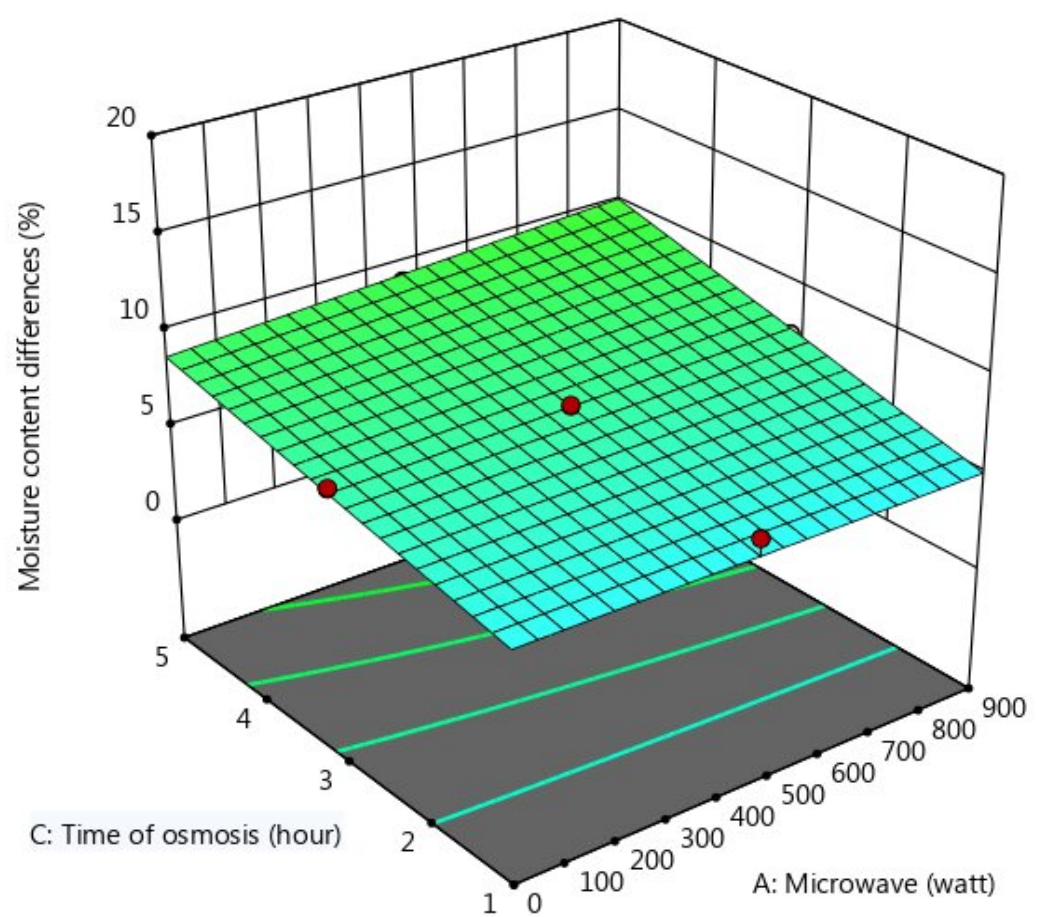

Figure 1. 3D image of the effect of microwave power and duration of osmosis on MD.

\section{Moisture content differences (\%) \\ - Design points above predicted value \\ Design points below predicted value 0.35 \\ 19.28}

$\mathrm{X} 1 \mathrm{~B}$ : Sugar concenteration $\mathrm{X} 2$ = C: Time of osmosis

Actual Factor

A: Microwave $=450$

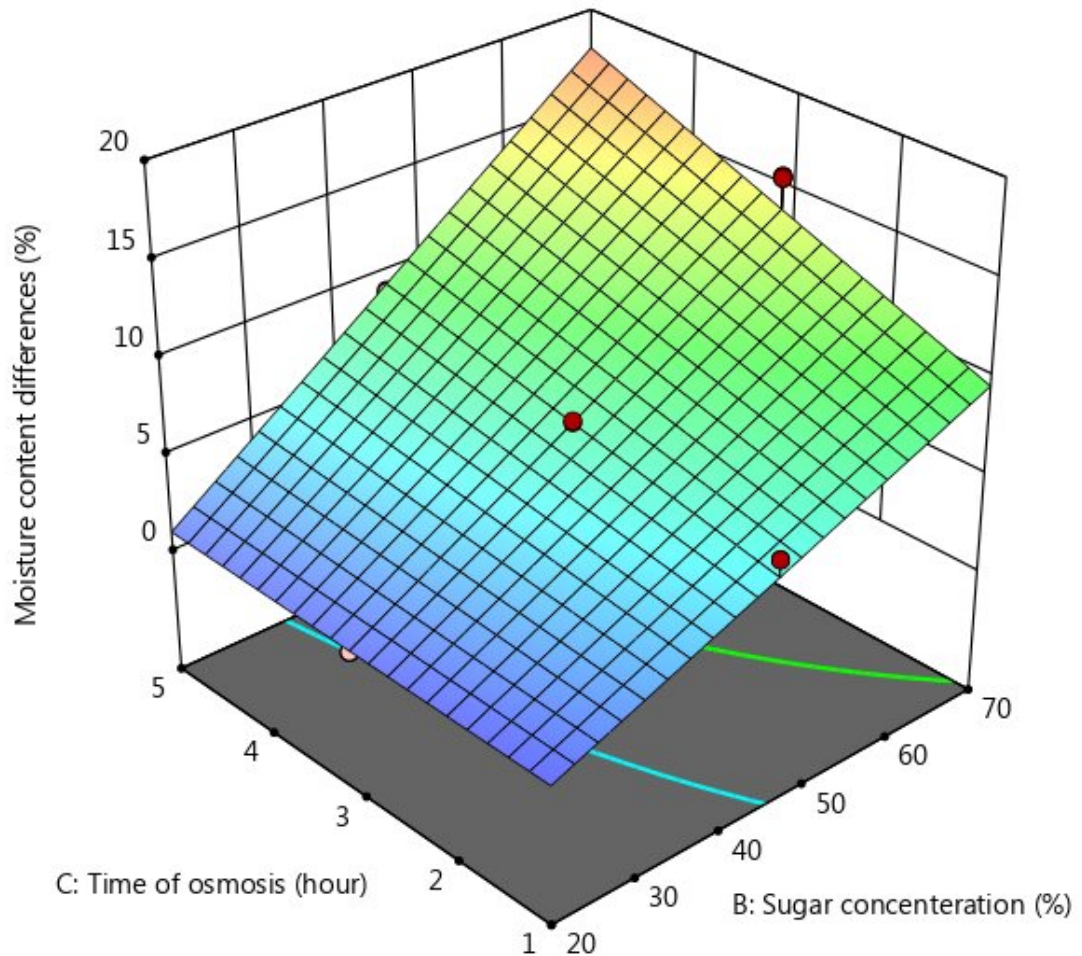

Figure 2. 3D image of the effect of osmotic solution concentration and duration of osmosis on the MD. 


\section{Water loss (\%)}

Design points above predicted value

Design points below predicted value 0.5712 25.7793

$\mathrm{X} 1$ = A: Microwave

$\mathrm{X} 2$ = B: Sugar concenteration

\section{Actual Factor}

C: Time of osmosis $=3$

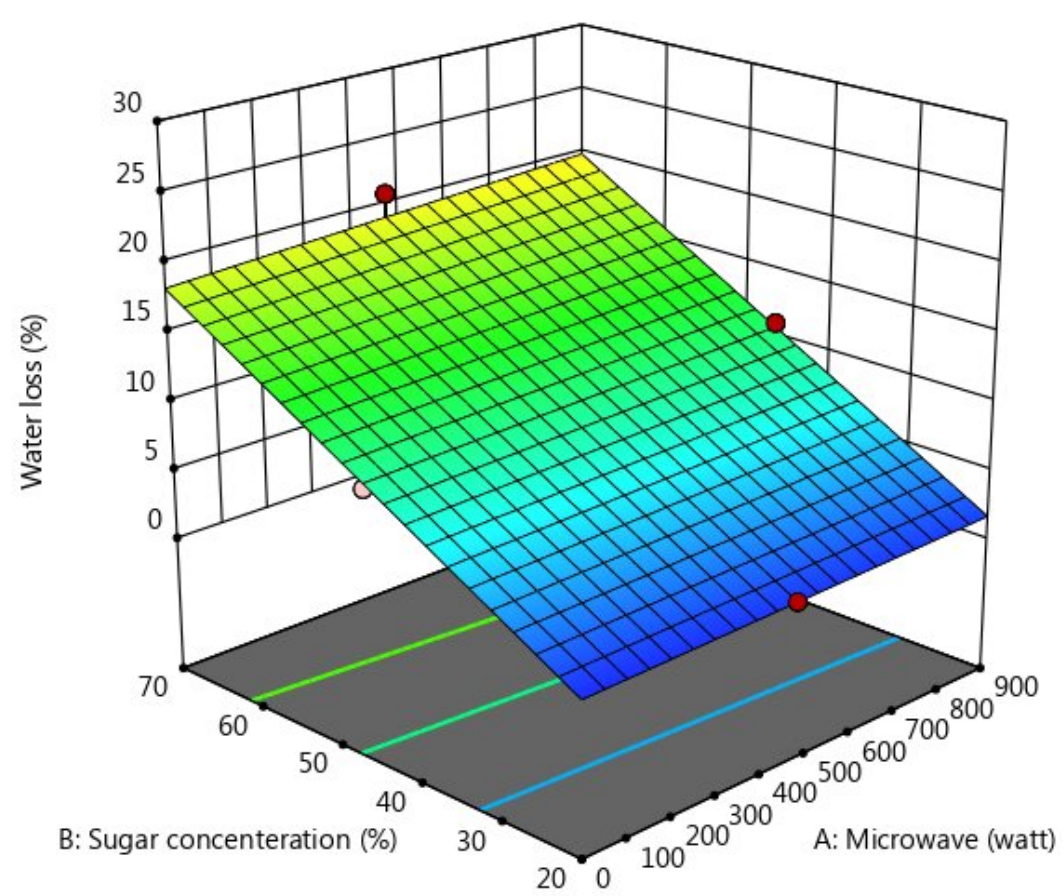

Figure 3. 3D image of the effect of osmotic solution concentration and microwave power on WL.

\section{Water loss (\%)}

Design points above predicted value

O Design points below predicted value 0.5712 25.7793

X1 = B: Sugar concenteration $\mathrm{X} 2=\mathrm{C}$ : Time of osmosis

\section{Actual Factor}

A: Microwave $=450$

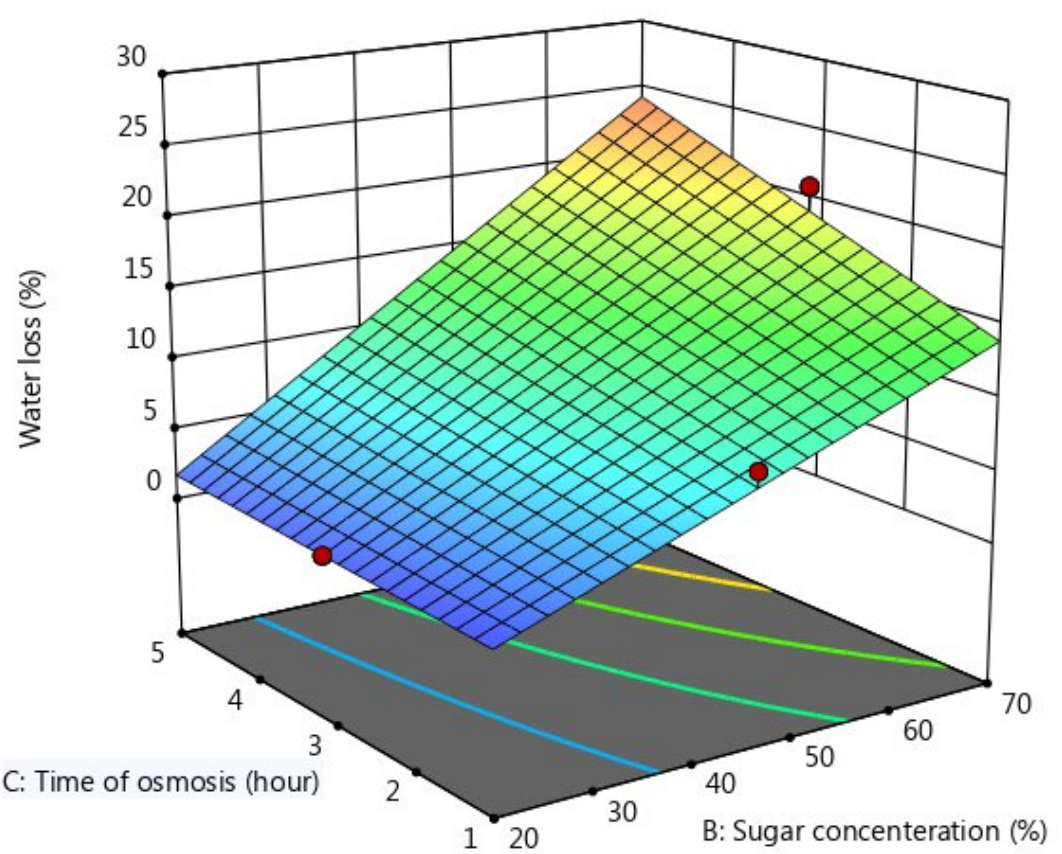

Figure 4. 3D image of the effect of osmotic solution concentration and duration of osmosis on WL. 
Optimization of coconut osmotic drying preceded by microwave treatment by Response Surface Methodology

Salimi, A., \& Hoseinnia, F.

\section{Solid gain (\%)}

O Design points above predicted value

O Design points below predicted value 0.1051 6.9286

$\mathrm{X} 1 \mathrm{=}$ : : Sugar concenteration $\mathrm{X} 2=\mathrm{C}$ : Time of osmosis

\section{Actual Factor}

A: Microwave $=450$

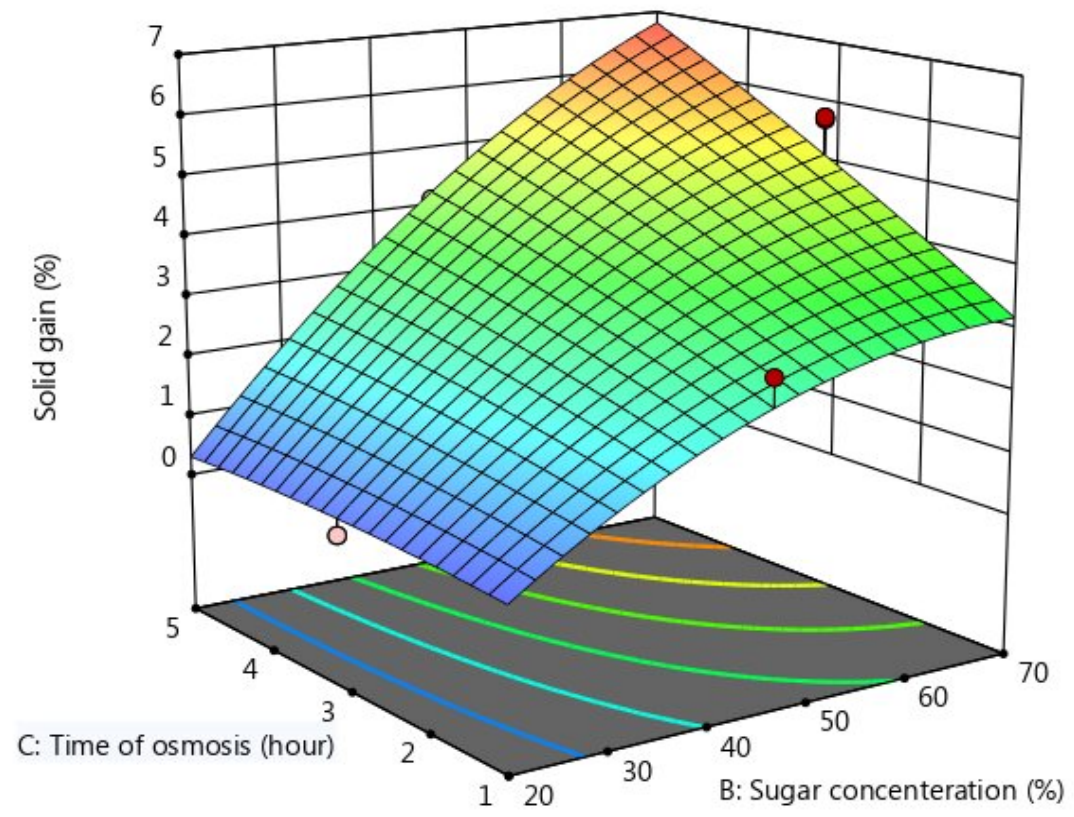

Figure 5. Effect of osmotic solution concentration and duration of osmosis on SG.

\section{Weight reduction (\%) \\ O Design points above predicted value \\ O Design points below predicted value \\ 0.45

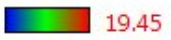

$\mathrm{X} 1$ = A: Microwave

$\mathrm{X}_{2}=\mathrm{B}$ : Sugar concenteration

\section{Actual Factor}

C: Time of osmosis $=3$

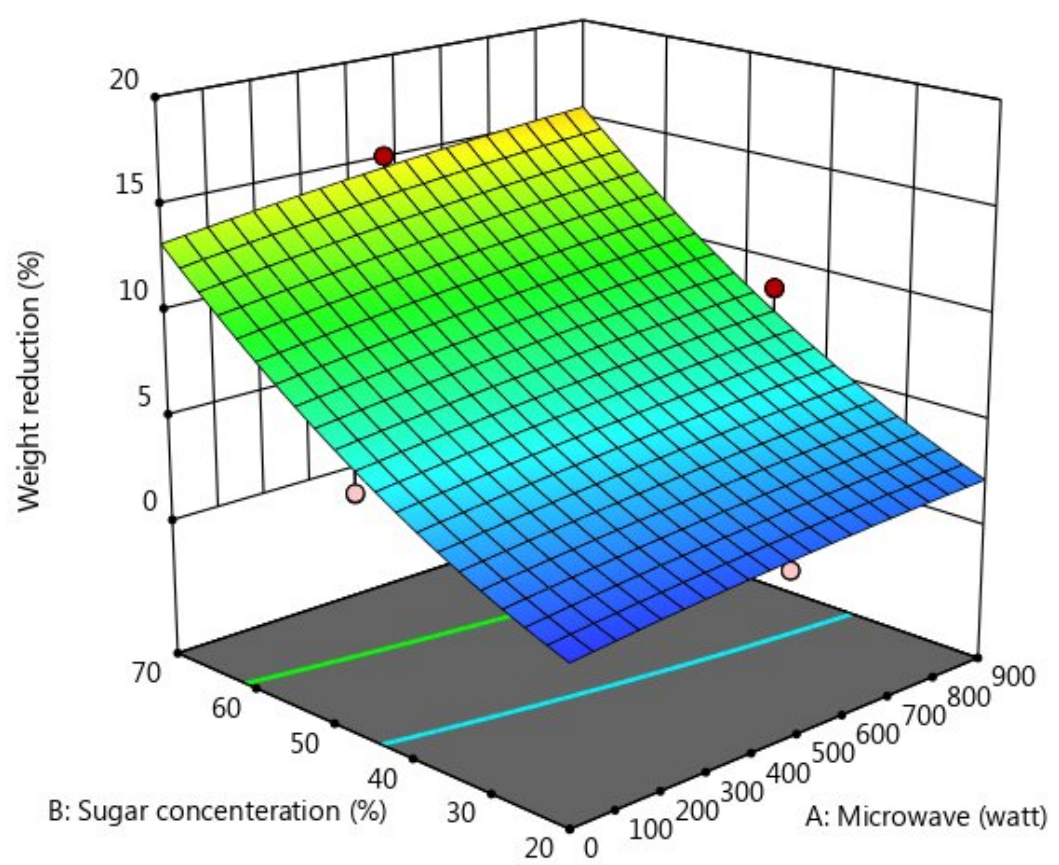

Figure 6. 3D image of the effect of osmotic solution concentration and microwave power on WR. 


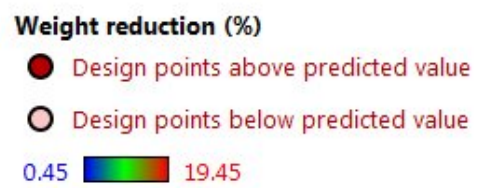

$\mathrm{X} 1$ = B: Sugar concenteration $\mathrm{X} 2$ = C: Time of osmosis

Actual Factor

A: Microwave $=450$

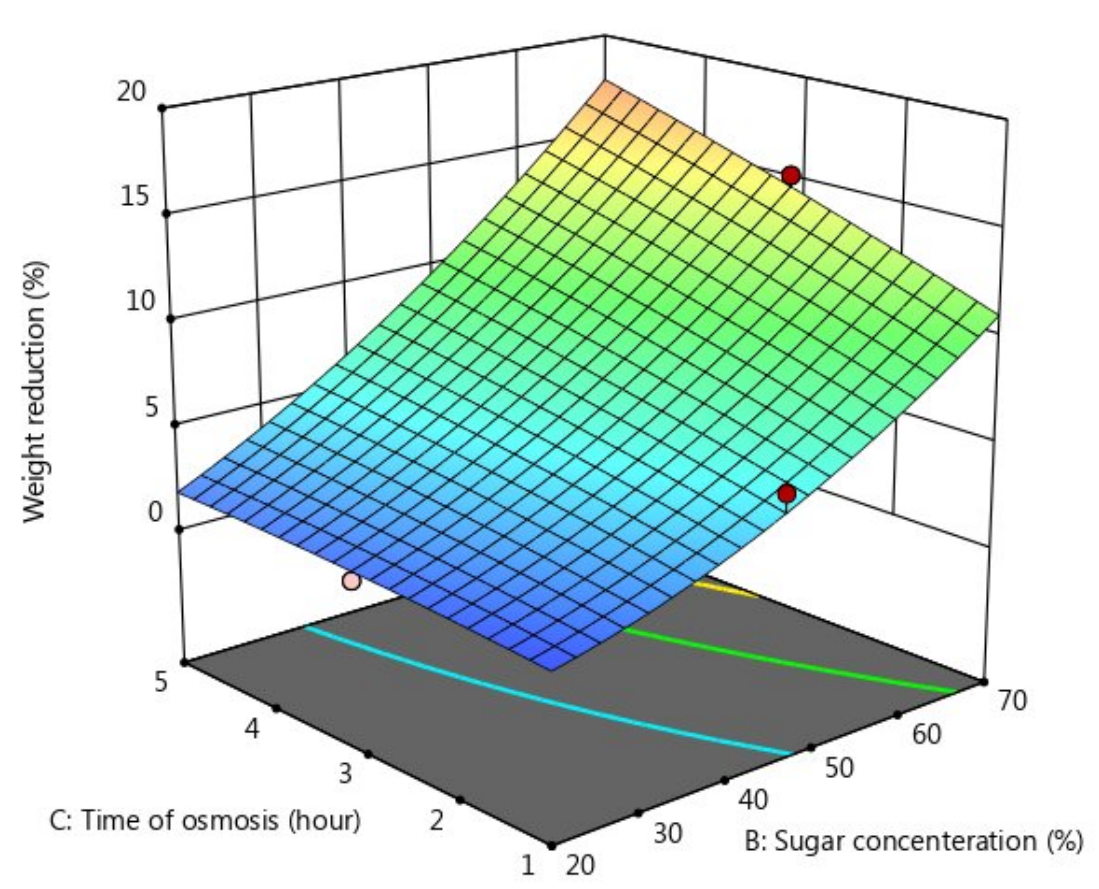

Figure 7. The 3D image of effect of osmotic solution concentration and duration of osmosis on WR.

By analyzing the data obtained, it can be seen that for all the dependent variables (MD, WL, WR and SG), the sugar concentration of the osmotic solution was the most significant independent variable $(p<0.05)$. It has been reported that increasing the concentration of the solution leads to higher osmotic pressure gradients which lead to greater WL (Phisut, 2012). Water loss itself, has a direct effect on the moisture content, so increments in the concentration of the solution have a significant impact on lowering the final moisture content and MD.

WR is a function of WL and SG. Greater WL and less SG result in a greater WR. On the other hand, higher sugar concentrations lead to greater osmotic pressure gradients, more solids gain and more water loss (Phisut, 2012; Kaur et al., 2014). The results presented in Table 3 show that both SG and WR were greatly affected by increasing the sugar concentration, but the changes in WR were more significant $(p<0.05)$. This indicates that higher sugar concentrations induced greater solids gains but that their effects on water loss were much more significant (Tables 1 and 2), which finally resulted in higher levels of weight reduction.

The present results were similar to those reported by El-Aouar et al. (2006), concerning the osmotic dehydration of papaya; by Sivasakthi \& Sangeetha (2012), concerning the osmotic dehydration of coconut; by Sabahi et al. (2013), on celery; by Aydani et al. (2013), on orange; by Deepika \& Murali Naik et al. (2017), on radish slices and by Liu \& Peng (2017), on strawberry.

The other independent variable which had a significant effect on all the dependent variables was the duration of osmosis $(p<0.05)$, and it has been reported that by increasing the sample immersion time, they will lose more water throughout their tissues (Mundada et al., 2011). Also, the SG and WR are totally related to the process time, its greatest effect being observed during the initial period of osmosis, consequently having a significant impact on further progression (Phisut, 2012; Shete et al., 2018).

Briefly one can say that with the passage of time so the reduction in weight is greater, but the rate of reduction slows down due to different factors such as the lowering of the level of free water in the tissue, dilution of the osmotic solution and inefficiency of the capillary tubes since they become plugged by solids, 
so a more lengthy treatment may be a useful way of increasing the water removal. It should be noted that this phenomenon is now a one-way flux and a longer period of osmosis can result in greater solids gains too. The present results were similar to those reported by El-Aouar et al. (2006), concerning papaya and by Deepika \& Gayathri (2015), concerning radish slices.

The third parameter with a great and significant effect on MD, WL, WR and SG, was the interaction between the sugar concentration and the duration of the process $(p<0.05)$. As mentioned above, the time and concentration were two important factors that could severely affect the independent variables due to the reasons given. The results indicated that the interaction of these two factors was even more effective than the microwave power. In fact, the longer the process time, combined with higher sugar concentrations, could have the benefit of both independent variable, in the same time. These results were similar to those reported by Yadav et al., 2012, concerning the osmotic dehydration of peach slices; by Shafiq \& Singh (2010), concerning the osmotic dehydration of Aonla slices and by Deepika \& Gayathri (2015), concerning radish slices.

According to the results obtained in the present research, the microwave power was the fourth important factor (after sugar concentration, duration and the interaction between them), but it only affected WL, WR and SG, and its interaction with duration significantly affected MD $(p<0.05)$.

Microwaves have a special heating mechanism due to their electromagnetic field, which leads to great fluctuations of polar molecules such as water. This phenomenon causes a rise in temperature in the depth of the samples as a result of friction, which leads to a rapid flow of water vapour from the inside to the outside of the product and to higher levels of WL and WR (Sumnu et al., 2005; Aghilinategh et al., 2015; Meda et al., 2016).

On the other hand, due to the rapid flow of vapour leaving the samples, and the high temperature inside the tissues, the SG increases due to softer and more porous tissue and the expansion phenomenon.

These results were similar to results presented by Aydani et al. (2013), on oranges, by Meda et al. 2016, on Saskatoon berries, by Karacabey et al. (2016) on Jerusalem artichokes and by Murali Naik et al. (2017) on potato.

\subsection{Optimized point}

Two essential parameters can reduce $a_{w}$ : loosing water and increasing the molecule content. In osmotic drying, the loss of more water has a direct impact on reducing $\mathrm{a}_{\mathrm{w}}$. However, on the other hand, the moisture content differences between the raw and processed materials, is another key factor. The greater the water removal, the higher the moisture content difference, which is the sign of a better osmotic dehydration process. Also, although greater solids gains lead to lower $a_{w}$ levels, this can have a bad effect on the organoleptic characteristics, and can change the original taste and flavor, so it is preferable to minimize the solids gain. Thus a greater weight reduction can be a sign of good process quality since it means the sample has lost more water with less solids gain (El-Aouar et al., 2006; Kamalanathan \& Meyyappan, 2014).

So based on the optimization processes, the best conditions for the microwave- osmosis drying of coconut samples were adjusted considering maximum levels for MD, WL and WR and minimum levels for SG. Thus in order to find the optimum conditions using software, the best range was defined for each independent variable, and the importance levels of each dependent variable then set. The greatest importance was given to MD and SG since these two variables could significantly represent the quality of the final product.

By adjusting the software, the final optimized point could be reached using a microwave power of 900 Watts, a sugar concentration of $47.80 \% \mathrm{w} / \mathrm{w}$ and 5 hours of osmotic process.

After finding the predicted optimized point, a sample was dried according to the proposed conditions and the independent variables examined and compared with the predicted ones. The results are shown in Table 4. 
Table 4. Predicted and experimental values for the responses at the optimized point.

\begin{tabular}{ccc}
\hline Responses & Predicted values & Experimental values \\
\hline MD & 11.16 & $10.09 \pm 1.34$ \\
\hline WL & 15.03 & $13.83 \pm 1.03$ \\
\hline SG & 4.09 & $4.012 \pm 0.73$ \\
\hline WR & 10.78 & $10.78 \pm 1.63$ \\
\hline
\end{tabular}

\section{Conclusion}

According to the results, all three independent variables had significant effects on the drying conditions of the samples directly or synergistically (interactive effect). In this case, the microwave power, sugar concentration and the duration of osmosis had significant effects on WL, SG and WR $(p<0.05)$. Also, the second order parameter of sugar concentration had a significant effect on SG and WR $(p<0.05)$.

The interaction effect between the microwave power and the sugar concentration had a significant effect on WL, MD and WR $(p<0.05)$, and the interaction effect of sugar concentration and the duration of the process significantly affected WL, SG and WR $(p<0.05)$.

The values for MD and WL were determined by two-factor models but quadratic models were required to correlate well with the data for WR and SG. The optimized point adjusted by the software showed that the optimum condition could be reached using a microwave power of 900 watts, a sugar concentration of $47.80 \%$ $\mathrm{w} / \mathrm{w}$ and a process time of 5 hours.

\section{References}

Aghilinategh, N., Rafiee, S., Hosseinpour, S., Omid, M., \& Mohtasebi, S. S. (2015). Optimization of intermittent microwaveconvective drying using response surface methodology. Food Science \& Nutrition, 3(4), 331-341. PMid:26286706. http://dx.doi.org/10.1002/fsn3.224

Askari, G. R., Emam-Djomeh, Z., \& Mousavi, S. M. (2004). Effect of combined coating and microwave assisted hot air drying on the texture, microstructure and rehydration characteristics of apple slices. Indian Journal of Agricultural Sciences, 35, 777-785.

Association of Official Analytical Chemists - AOAC. (2005). Official methods of analysis (18th ed.). Arlington: AOAC.

Aydani, A., Kashani Nejad, M., \& Bakhsh Abadi, H. (2013). Orange osmotic dehydration process optimization and parameter estimation method call level of dehydration with the help of artificial neural network. Research Journal of Food Science and Technology, 9(3), 202-214.

Behnam, P., Karajyan, H., Hahidi, S., Noghabi, M., \& Parvini, M. (2013). Process optimization using osmotic dehydration of banana. Journal of Food Science and Technology Innovation, 5(2), 83-89.

Chenlo, F., Moreira, R., Fernández-Herrero, C., \& Vázquez, G. (2006). Experimental results and modeling of the osmotic dehydration kinetics of chestnut with glucose solutions. Journal of Food Engineering, 74(3), 324-334. http://dx.doi.org/10.1016/j.jfoodeng.2005.03.002

Corrêa, J. L. G., Rasia, M. C., Mulet, A., \& Cárcel, J. A. (2016). Influence of ultrasound application on both the osmotic pretreatment and subsequent convective drying of pineapple (Ananas comosus). Innovative Food Science \& Emerging Technologies, 41, 284-291. http://dx.doi.org/10.1016/j.ifset.2017.04.002

Deepika, K., \& Gayathri, V. (2015). Optimization of process parameters on osmotic dehydration of radish slices using Response Surface Methodology (RSM). International Journal of Pharmaceutical Sciences and Business Management, 3(3), 1-10.

Durance, T. D., \& Wang, J. H. (2002). Energy consumption, density, and rehydration rate of vacuum microwave- and hot-air convection-dehydrated tomatoes. Journal of Food Science, 67(6), 2212-2216. http://dx.doi.org/10.1111/j.13652621.2002.tb09529.x

El-Aouar, A. A., Azoubel, P. M., Barbosa Junior, J. L., \& Xidieh Murr, F. E. (2006). Influence of the osmotic agent on the osmotic dehydration of papaya (Carica papaya). Journal of Food Engineering, 75(2), 267-274. http://dx.doi.org/10.1016/j.jfoodeng.2005.04.016

Eroglu, E., \& Yildiz, H. (2010). Recent developments in osmotic dehydration. Akademik Gıda, 8(6), 24-28.

Herman-Lara, A., Martínez-Sánchez, C. E., Pacheco-Angulo, H., Carmona-García, R., Ruiz-Espinosa, H., \& Ruiz-López, I. I. (2013). Mass transfer modeling of equilibrium and dynamic periods during osmotic dehydration of radish in $\mathrm{NaCl}$ solutions. Food and Bioproducts Processing, 91(3), 216-224. http://dx.doi.org/10.1016/j.fbp.2012.10.001

Islam, M. N., \& Flink, J. N. (1982). Dehydration of potato. International Journal of Food Science \& Technology, 17(3), 387-403. http://dx.doi.org/10.1111/j.1365-2621.1982.tb00194.x 
Junqueira, J. R. J., Corrêa, J. L. G., Mendonça, K. S., Mello Júnior, R. E., \& Souza, A. U. (2018). Pulsed vacuum osmotic dehydration of beetroot, carrot and eggplant slices: Effect of vacuum pressure on the quality parameters. Food and Bioprocess Technology, 11(10), 1863-1875. http://dx.doi.org/10.1007/s11947-018-2147-9

Kamalanathan, G., \& Meyyappan, R. M. (2014). Osmotic drying out of coconut slices in salt solution: Optimization of process parameters using response surface methodology. International Journal of Chemistry Technology and Research, 7(6), 27732785.

Karacabey, E., Baltacioglu, C., Cevik, M., \& Kalkan, H. (2016). Optimization of microwave-assisted drying of Jerusalem artichokes (Helianthus tuberosus L.) by response surface methodology and genetic algorithm. Italian Journal of Food Science, $28,121-130$.

Kaur, K., Kumar, S., \& Alam, M. S. (2014). Air drying kinetics and quality characteristics of oyster mushroom (Pleurotus ostreatus) influenced by osmotic dehydration. Agricultural Engineering International: CIGR Journal, 16(3), 214-222.

Liu, B., \& Peng, B. (2017). Modelling and optimization of process parameters for strawberry osmotic dehydration using central composite rotatable design. Journal of Food Quality, 2017, 1-7. http://dx.doi.org/10.1155/2017/2593213

Meda, V., Mitra, P., Lee, J. H., \& Chang, K. S. (2016). Optimization of microwave-vacuum drying processing parameters on the physical properties of dried Saskatoon berries. Open Agriculture, 1(1), 7-17. http://dx.doi.org/10.1515/opag-2016-0002

Misljenovic, N. M., Koprivica, G. B., Pezo, L. L., Levic, L. B., Curcic, B. L., Filipovic, V. S., \& Nicetin, M. R. (2012). Optimization of the osmotic dehydration of carrot cubes in sugar beet molasses. Thermal Science, 16(1), 43-52.

http://dx.doi.org/10.2298/TSCl110808129M

Mundada, M., Hathan, S. B., \& Maske, S. (2011). Mass transfer kinetics during osmotic dehydration of pomegranate arils. Journal of Food Science, 76(1), 31-39. PMid:21535673. http://dx.doi.org/10.1111/j.1750-3841.2010.01921.x

Murali Naik, K., Lakshmi Bala, K., \& Srinivas, D. (2017). Optimization of osmotic dehydrated microwave frying of potato slices. International Journal of Pure and Applied Bioscience, 5(4), 1917-1930. http://dx.doi.org/10.18782/2320-7051.5596

Phisut, N. (2012). Factors affecting mass transfer during osmotic dehydration of fruits. International Food Research Journal, 19(1), 7-18.

Quanhong, L., \& Caili, F. (2005). Application of response surface methodology: For extraction optimization of germinant pumpkin seeds protein. Food Chemistry, 92(4), 701-706. http://dx.doi.org/10.1016/j.foodchem.2004.08.042

Ramya, V., \& Jain, N. K. (2017). A review on osmotic dehydration of fruits and vegetables: An integrated approach. Food Process Engineering, 40(3), 1-22. http://dx.doi.org/10.1111/jfpe.12440

Sabahi, S., Shafafi Zenozian, M., \& Mortezavi, S. A. (2013). Check the microwave treatment and the salt osmotic solution on drying celery. In 2nd National Conference on Food Science and Technology. Quchan: Islamic Azad University of Quchan.

Shafiq, A., \& Singh, A. (2010). Optimum process parameters for development of sweet aonla flakes. International Journal of Research and Reviews in Applied Sciences, 3(3), 323-333.

Shete, Y. V., Chavan, S. M., Champawat, P. S., \& Jain, S. K. (2018). Reviews on osmotic dehydration of fruits and vegetables. Journal of Pharmacognosy and Phytochemistry, 7(2), 1964-1969.

Silva, W. P., Silva, C. M. D. P. S., Farias Aires, J. E., \& Silva Junior, A. F. (2014). Osmotic dehydration and convective drying of coconut slices: Experimental determination and description using one-dimensional diffusion model. Journal of the Saudi Society of Agricultural Sciences, 13(2), 162-168. http://dx.doi.org/10.1016/j.jssas.2013.05.002

Sivasakthi, M., \& Sangeetha, N. (2012). Development of Cocos nucifera chips impregnating Beta vulgaris extract as an osmotic medium. Gida, 37(6), 317-324.

Sousa, F. W., Moreira, S. A., Oliveira, A. G., Cavalcante, R. M., Nascimento, R. F., \& Rosa, M. F. (2007). The use of green coconut shells as adsorbents in the removal of toxic metals. Quimica Nova, 30(5), 1153-1157. http://dx.doi.org/10.1590/S010040422007000500019

Sumnu, G., Turabi, E., \& Oztop, M. (2005). Drying of carrots in microwave and halogen lamp-microwave combination ovens. Lebensmittel-Wissenschaft + Technologie, 38(5), 549-553. http://dx.doi.org/10.1016/j.Iwt.2004.07.006

Valadez-Carmona, L., Cortez-García, R. M., Plazola-Jacinto, C. P., Necoechea-Mondragón, H., \& Ortiz-Moreno, A. (2016). Effect of microwave drying and oven drying on the water activity, color, phenolic compounds content and antioxidant activity of coconut husk (Cocos nucifera L.). Journal of Food Science and Technology, 53(9), 3495-3501. PMid:27777455. http://dx.doi.org/10.1007/s13197-016-2324-7

Zhang, M., Tang, J., Mujumdar, A., \& Wang, S. (2006). Trends in microwave-related drying of fruits and vegetables. Trends in Food Science \& Technology, 17(10), 524-534. http://dx.doi.org/10.1016/j.tifs.2006.04.011 